\title{
Safety and efficacy of intravenous iron therapy in reducing requirement for allogeneic blood transfusion: systematic review and meta-analysis of randomised clinical trials
}

\begin{abstract}
Objectives To evaluate the efficacy and safety of intravenous iron, focusing primarily on its effects on haemoglobin, requirement for transfusion, and risk of infection.

Design Systematic review and meta-analysis of randomised controlled trials investigating the safety and efficacy of intravenous iron therapy.

Data sources Randomised controlled trials from Medline, Embase, and the Cochrane Central Register of Controlled Trials from 1966 to June 2013, with no language restrictions.

Eligibility criteria for selecting studies Eligible trials were randomised controlled trials of intravenous iron compared with either no iron or oral iron. Crossover and observational studies were excluded.

Main outcome measures Change in haemoglobin concentration and risk of allogeneic red blood cell transfusion (efficacy) and risk of infection (safety).

Results Of the 75 trials meeting the inclusion criteria, 72 studies including 10605 patients provided quantitative outcome data for meta-analysis Intravenous iron was associated with an increase in haemoglobin concentration (standardised mean difference $6.5 \mathrm{~g} / \mathrm{L}, 95 \%$ confidence interval $5.1 \mathrm{~g} / \mathrm{L}$ to $7.9 \mathrm{~g} / \mathrm{L}$ ) and a reduced risk of requirement for red blood cell transfusion (risk ratio $0.74,95 \%$ confidence interval 0.62 to 0.88 ), especially when intravenous iron was used with erythroid stimulating agents (ESAs) or in patients with a lower baseline plasma ferritin concentration. There were no significant interactions between the efficacy of intravenous iron and type or dose administered. Intravenous iron was, however, associated with a significant increase in risk of infection (relative risk $1.33,95 \%$ confidence interval 1.10 to
\end{abstract}

\begin{abstract}
1.64) compared with oral or no iron supplementation. The results remained similar when only high quality trials were analysed.
\end{abstract}

Conclusions Intravenous iron therapy is effective in increasing haemoglobin concentration and reducing the risk of allogeneic red blood cell transfusion and could have broad applicability to a range of acute care settings. This potential benefit is counterbalanced by a potential increased risk of infection.

\section{Introduction}

Iron is essential for the production of red blood cells and is the most common nutritional deficiency worldwide, both in developed and developing countries. ${ }^{1}$ Though allogeneic red blood cell transfusion might be lifesaving for the management of acute severe blood loss, there are increasing concerns about associated serious adverse events, costs, and scarcity. ${ }^{2}$ Safe and effective strategies to reduce such transfusions are urgently needed.

Correction of iron deficiency anaemia with oral iron is limited by gastrointestinal absorption and is particularly ineffective in the setting of coexisting acute or chronic medical conditions. ${ }^{3}$ Supported by laboratory results, intravenous iron therapy has an established role in the treatment of iron deficiency anaemia, when oral preparations are ineffective or cannot be used. ${ }^{4}$ Recent advances in the understanding of iron metabolism and the association between allogeneic red blood cell transfusion and adverse outcomes has increased the interest in the use of intravenous iron to reduce requirement for red blood cell transfusion in various acute clinical settings. ${ }^{56}$ Although older 
intravenous iron preparations were associated with a risk of anaphylaxis, newer preparations have largely alleviated this problem. ${ }^{7}$ Nevertheless, whether intravenous iron is associated with other important adverse events, in particular the theoretical risk of infection, remains uncertain. ${ }^{8-10}$

In this systematic review and meta-analysis, undertaken according to PRISMA guidelines, ${ }^{11}$ we evaluated the safety and efficacy of intravenous iron, focusing primarily on its effects on requirement for transfusion and risk of infection.

\section{Methods \\ Eligibility criteria}

We searched for randomised controlled trials in which intravenous iron was compared with either oral iron or no iron supplementation. Studies were excluded if they were randomised but with a crossover design, observational, did not report an outcome of interest, provided insufficient data for outcomes to be reported, or did not contain a group or subgroup in which the independent effect of intravenous iron could be assessed. The primary outcomes of interest were change in haemoglobin concentration and risk of transfusion (efficacy) and risk of infection (safety). Secondary outcomes of interest included adverse events and serious adverse events as defined by the primary studies, anaphylaxis, mortality, length of hospital stay, cost, and cost effectiveness.

\section{Search strategy}

The primary search was conducted with Medline, Embase and the Cochrane Central Register of Controlled Trials for randomised trials with the terms "iron" and "ferric compounds" and "intravenous." The search included the time period from 1966 to June 2013 and was conducted without language restrictions. We searched the reference lists of all included studies as well as relevant review articles and conference proceedings. The manufacturers of intravenous iron formulations were also contacted to request access to unpublished trial data.

Two authors (EL and JX) independently conducted the primary search. When we were uncertain about eligibility or needed additional data on endpoints, we contacted the corresponding author to request further information.

\section{Study selection}

Two authors (EL and JX) retrieved potentially relevant titles for full text review and transcribed data from eligible studies onto a prespecified proforma. Studies that were published only in abstract form were excluded. Disagreement on study inclusion or endpoints was resolved by the third author (KMH).

\section{Data analysis}

Our primary outcomes of interest were efficacy (change in haemoglobin concentration and proportion of patients requiring allogeneic red blood cell transfusion) and safety (all cause infection). When studies included both oral iron and no iron comparison groups, we preferentially compared intravenous iron with oral iron. For categorical data, the risk of an outcome was defined as the number of patients with an event compared with the number of patients with and without an event. For continuous data, we used mean, standard deviation, and participant number. Data from studies fulfilling the eligibility were pooled for meta-analysis with a random effects model. Studies with no events in one of the study groups were included as this has been shown to provide a more valid estimate of true treatment effect. ${ }^{12}$ We calculated standardised mean difference and risk ratio with $95 \%$ confidence interval for continuous and categorical outcomes, respectively, and $\mathrm{P}<0.05$ was taken as significant. Heterogeneity was assessed with the $\mathrm{I}^{2}$ statistic, and $\mathrm{I}^{2}>40 \%$ was considered as significant heterogeneity. Meta-regression was undertaken to examine the effect of intravenous iron dose and baseline iron on the associations between intravenous iron and the primary outcomes.

We carried out a sensitivity analysis on the efficacy (transfusion) and safety (infection) outcomes by excluding studies with a high risk of bias for one or more key domains using the Cochrane Collaboration's tool for assessing risk of bias. ${ }^{13}$ Publication bias was assessed with a funnel plot, plotting the odds ratio for proportion transfused against the standard error of the log odds ratio. The statistical analysis was conducted with Stata (Intercooled Version 11.2, StataCorp, College Station, TX, USA) and Comprehensive Meta-analysis (version 2.2.034, Biostat, USA, 2006).

\section{Results}

The initial electronic search returned 1815 citations. After examination of the titles and abstracts, we retrieved 126 for more detailed examination. A total of 75 studies including 10 879 participants fulfilled the inclusion criteria and were included in the systematic review (appendix 1). ${ }^{14-88}$ Of the included studies, 72 including 10605 participants provided sufficient quantitative outcome data to be included in the primary meta-analyses. Figure 1 show details of study inclusion $\Downarrow$.

\section{Study characteristics and validity assessment}

The number of participants in the included studies varied between 25 and 507, and studies were carried out in a wide range of clinical specialties (renal $n=19$, obstetric $n=19$, surgical $n=11$, oncology/haematology $n=11$, cardiology $n=4$, gastroenterology $n=4$, other $n=7$ ). The baseline haemoglobin concentration (mean range 60-145 g/L) and ferritin concentration (mean range ferritin $70-7610 \mathrm{ng} / \mathrm{mL}$ ), of the included patients also varied between studies. The most common intravenous iron preparation used in the included studies was iron sucrose $(n=42)$, followed by iron gluconate $(n=10)$ and ferric carboxymaltose $(n=10)$. Dextran iron was used in seven studies; six further studies used other iron preparations. Efficacy outcomes, including change in haemoglobin concentration and transfusion, were variably reported, as were safety outcomes including infection, mortality, serious adverse events, and anaphylaxis. Appendix 1 shows the characteristics of the included studies.

Overall, the risk of bias was low for 18 studies and high for 57 studies. The overall high risk of bias was accounted for by most studies not being blinded to participants or study personnel $(\mathrm{n}=56)$.

The authors of nine studies provided addition data for inclusion in the systematic review. Appendix 2 shows the results of the validity assessment.

\section{Quantitative data synthesis}

\section{Change in haemoglobin concentration and proportion of patients requiring allogeneic red blood cell transfusion}

A total of 59 studies comprising 7610 participants reported the change in haemoglobin concentration before and after treatment (appendix 3). When data were pooled, intravenous iron was associated with a significant increase in standardised mean haemoglobin concentration $(6.5 \mathrm{~g} / \mathrm{L}, 95 \%$ confidence interval 
$5.1 \mathrm{~g} / \mathrm{L}$ to $7.9 \mathrm{~g} / \mathrm{L})$ compared with oral iron or no iron supplementation (fig $2 \Downarrow$ ). There was significant heterogeneity between the studies $\left(\mathrm{I}^{2}=87.7 \%, \mathrm{P}<0.01\right)$.

A total of 22 studies comprising 3321 participants reported on the risk of requiring allogeneic red blood cell transfusion. Intravenous iron therapy was associated with a significant reduction in risk (risk ratio $0.74,95 \%$ confidence interval 0.62 to 0.88$)$, without significant heterogeneity $\left(\mathrm{I}^{2}=9 \%, \mathrm{P}=0.3\right.$; fig $3 \Downarrow)$.

There was a potential interaction between use of erythroid stimulating agents and the effect of intravenous iron therapy, with a greater effect of intravenous iron on reducing risk of requiring transfusion with concurrent use of erythroid stimulating agents (slope of the regression line $0.32,95 \%$ confidence interval 0.02 to 0.63 ; P=0.04; fig $4 \Downarrow$ ). Similarly, a lower baseline ferritin concentration was associated with greater therapeutic effect in reducing the risk ratio of requiring red blood cell transfusion after intravenous iron therapy (slope of the regression line $0.002,95 \%$ confidence interval 0.002 to 0.004; $\mathrm{P}=0.04)$. There was, however, no interaction between baseline transferrin saturation and risk of requiring red blood cell transfusion after intravenous iron therapy.

\section{Effect of intravenous iron on all cause infection}

After we excluded three studies with no events in both intervention and comparison groups, ${ }^{45-74} 24$ studies $(n=4400)$ reported data on risk of infection after intravenous iron compared with either oral iron or no iron supplementation (appendix 3). Intravenous iron was associated with a significant increase in risk of infection of 1.33 (95\% confidence interval 1.10 to 1.64 ; figure $5 \Downarrow$ ), with no significant heterogeneity $\left(\mathrm{I}^{2}=22.7 \%, \mathrm{P}=0.2\right)$.

Increased risk of infection was observed in studies comparing intravenous iron with oral iron and in those comparing intravenous iron with no iron. There was no interaction between baseline ferritin, transferrin saturation, iron per dose, or erythroid stimulating agents and risk of infection.

\section{Effect of intravenous iron therapy on other safety endpoints}

There was no significant difference in mortality (risk ratio 1.1, $95 \%$ confidence interval 0.8 to 1.5 ) or serious adverse events (1.1, 0.9 to 1.2 ) with intravenous iron therapy in 20 and 19 trials, respectively. Adverse events were also not significantly different between intravenous iron therapy and oral iron or no supplemental iron $(0.9,0.8$ to 1.1$)$. Of the 32 studies that on reporting anaphylaxis, there were eight cases in participants receiving intravenous iron $(n=2186)$.

\section{Sensitivity analysis and publication bias}

Exclusion of studies with high risk of bias according to the Cochrane Collaboration's tool for assessing risk of bias ${ }^{13}$ limited the meta-analysis of risk of transfusion to only five studies $(n=901),{ }^{34-78}$ and this did not change the direction of the association between intravenous iron and risk of requiring allogeneic red blood cell transfusion, but the association was no longer significant (risk ratio $0.8,95 \%$ confidence interval 0.6 to $1.1 ; \mathrm{P}=0.66$ ). The sensitivity analysis for risk of infection limited the meta-analysis to eight studies ${ }^{20-78}$ and did not substantially change the direction and magnitude of the association between intravenous iron therapy and risk of infection $(1.4,1.0$ to $1.8 ; \mathrm{P}=0.03)$. There was no evidence of publication bias in reporting requirement for allogeneic red blood cell transfusion in the pooled studies (fig $6 \Downarrow$ ).

\section{Discussion}

In this large systematic review and meta-analysis assessing safety and efficacy in patients in many specialties we have shown that intravenous iron is effective in increasing haemoglobin concentration and reducing the risk of allogeneic red blood cell transfusion but is associated with an increased risk of all cause infection. Intravenous iron is increasingly advocated to treat anaemia with the aim of reducing the need for allogeneic red blood cell transfusion; the risks and benefits of intravenous iron, however, remain uncertain.

\section{Reducing requirement for allogeneic red blood cell transfusion}

Allogeneic red blood cell transfusion is associated with an increased risk of serious adverse events, including mortality. ${ }^{89}$ In this meta-analysis, we confirmed that intravenous iron is effective in reducing the requirement for red blood cell transfusion and thereby reducing associated risk. This benefit seemed consistent across different categories of disease and formulations of intravenous iron and was present whether intravenous iron was compared with oral iron or no iron. These findings are in keeping with recent advances in the understanding of iron metabolism; intravenous iron is more effective than oral iron, particularly in the setting of acute or chronic inflammation, by bypassing the effects hepcidin—an inhibitor of gastrointestinal iron absorption. ${ }^{90}$ As such, intravenous iron might have an important role in the management of patients as part of a strategy to reduce requirement for allogeneic red blood cell transfusion for many patients in hospital.

Additionally, we have shown that the effect of intravenous iron on the risk of requiring allogeneic red blood cell transfusion can be further enhanced by concomitant use of erythroid stimulating agents. None of the studies included in the transfusion meta-analysis were conducted in patients with chronic renal failure, in whom use of erythroid stimulating agents is standard. The use of these agents alone could induce a state of functional iron deficiency and has been postulated as a potential mechanism for the negative results of previous studies on use of erythroid stimulating agents in critical care..$^{91} 92$ Whether the addition of intravenous iron to erythroid stimulating agents in this setting is beneficial requires further investigation.

\section{Iron and risk of infection}

The reduction in allogeneic red blood cell transfusion must be considered alongside our finding of an increased risk of all cause infections after intravenous iron therapy. Free iron has been shown to potentiate bacterial growth in vitro. ${ }^{8}$ Clinical evidence on the association between intravenous iron therapy and infection, however, has been inconclusive, with no increase in infection observed with intravenous iron therapy in patients undergoing dialysis or in patients after surgery or in a mouse model of critical care anaemia. ${ }^{9-94}$ This discrepancy might be explained by the low free iron concentrations associated with newer intravenous iron preparations. ${ }^{95} 96$ Our finding might also be a false positive result. Infection was not a predefined endpoint in many pooled studies, and it is possible that missing data could have created unmeasured bias in our analysis. Furthermore, we could not find a significant association between iron dose and risk of infection, and, overall, serious adverse events and mortality were not significantly increased in those receiving intravenous iron compared with oral or no iron. Until randomised controlled trials of intravenous iron adequately powered for patient centred outcomes are available, including 
standardised definitions for infection, it might be preferable to use intravenous iron preparations associated with relatively low free iron concentrations.

Although this was a large comprehensive systematic review, several limitations bear consideration. Firstly, data on all outcomes were not available from each study, and the doses and preparations of intravenous iron used in the pooled studies varied. Nevertheless, heterogeneity in the risk of requiring transfusion and infection was low, and the number of studies available was sufficient to conduct several meta-regression analyses to assess the interaction between different predictors and efficacy of intravenous iron therapy in increasing haemoglobin concentration. Previous smaller systematic reviews of intravenous iron therapy were unable to provide sufficient data to estimate important outcomes such as risk of infection or to assess the effect of different predictors on efficacy. ${ }^{97} 98$ Secondly, the quality of the included studies was variable, and the overall risk of bias in the included studies was high, despite exclusion of studies that had not been published in full. Finally, meta-regression of trial characteristics with participant level characteristics, such as baseline ferritin concentration, could lead to aggregation bias and might be underpowered to detect true differences, such as the effect of type and dose of intravenous iron.${ }^{99}$ We included a large number of studies and conducted meta-regression only when heterogeneity was low on forest plot based on an a priori defined criterion of non-significant heterogeneity $\left(\mathrm{I}^{2}<40 \%\right)$, which reduces but cannot completely exclude the risk of bias.

\section{Conclusion}

Intravenous iron therapy is associated with a significantly reduced risk of need for an allogeneic red blood cell transfusion. These findings suggest that intravenous iron might have broad applicability to many patients in hospital, in whom anaemia is common. This benefit is counterbalanced by a potential increased risk of infection. Further randomised controlled trials of intravenous iron are required to define whether it should be used as a first line treatment to reduce allogeneic red blood cell transfusions in patients in hospital. Such trials should include well defined infection endpoints and be adequately powered for important patient centred endpoints including mortality and major morbidity.

We thank all the authors whose work contributed to this manuscript; particularly those who provided additional study data, L Bastit, L Grote, M Hedenus, A Khalafallah, PA Krayenbuehl, S Kulnigg, S Lindgren, JA Serrano-Trenas, and DP Steensma.

Contributors: EL had the concept for the study, EL and KMH designed the study, EL JX, and KMH conducted the analysis, interpretation of the data and drafted the manuscript. EL, JX, and KMH all approved the final version to be published. EL is guarantor.

Funding: This research received no specific grant from any funding agency in the public, commercial, or not-for-profit sectors.

Competing interests: All authors have completed the ICMJE uniform disclosure form at www.icmje.org/coi_disclosure.pdf (available on request from the corresponding author) and declare that $E L$ has received supply of an intravenous iron preparation from Vifor Pharma for an upcoming study.

Ethical approval: Not required.

Data sharing: No additional data available.

1. Mclean E. Worldwide prevalence of anaemia 1993-2005. World Health Organization, 2008.

2 Isbister JP, Shander A, Spahn DR, Erhard J, Farmer SL, Hofmann A. Adverse blood transfusion outcomes: establishing causation. Transfus Med Rev 2011;25:89-101.
3 Goodnough LT. Iron deficiency syndromes and iron-restricted erythropoeisis. Transfusion 2012;52:1584-92.

$4 \quad \mathrm{KDOQI}$, National Kidney Foundation. II. Clinical practice guidelines and clinical practice recommendations for anemia in chronic kidney disease in adults. Am J Kidney Dis 2006;47(5 suppl 3):S16-85

5 Hofmann A, Farmer S, Towler SC. Strategies to preempt and reduce the use of blood products: an Australian perspective. Curr Opin Anaesthesiol 2012;25:66-73

6 Shander A, Spence RK, Auerbach M. Can intravenous iron therapy meet the unmet needs created by the new restrictions on erythropoietic stimulating agents? Transfusion 2010;50:719-32.

7 Lyseng-Williamson KA, Keating GM. Ferric carboxymaltose: a review of its use in iron-deficiency anaemia. Drugs 2009;69:739-56.

8 Fishbane S. Review of issues relating to iron and infection. Am J Kidney Dis 1999;34(4 suppl 2):S47-52.

9 Maynor L, Brophy DF. Risk of infection with intravenous iron therapy. Ann Pharmacother 2007;41:1476-80.

10 Notebaert E, Chauny JM, Albert M, Fortier S, Leblanc N, Williamson DR. Short-term benefits and risks of intravenous iron: a systematic review and meta-analysis. Transfusion 2007;47:1905-18.

11 Moher D, Liberati A, Tetzlaff J, Altman DG. Preferred reporting items for systematic reviews and meta-analyses: the PRISMA statement. Ann Intern Med 2009;151:264-9, W64.

12 Friedrich JO, Adhikari NK, Beyene J. Inclusion of zero total event trials in meta-analyses maintains analytic consistency and incorporates all available data. BMC Med Res Methodo 2007;7:5.

13 Higgins JP, Altman DG, Gotzsche PC, Juni P, Moher D, Oxman AD, et al. The Cochrane Collaboration's tool for assessing risk of bias in randomised trials. BMJ 2011;343:d5928.

14 Neeru S, Nair NS, Rai L. Iron sucrose versus oral iron therapy in pregnancy anemia. Indian J Community Med 2012;37:214-8.

15 Adhikary L, Acharya S. Efficacy of IV iron compared to oral iron for increment of haemoglobin level in anemic chronic kidney disease patients on erythropoietin therapy. JNMA J Nepal Med Assoc 2011;51:133-6.

16 Agarwal R, Rizkala AR, Bastani B, Kaskas MO, Leehey DJ, Besarab A. A randomized controlled trial of oral versus intravenous iron in chronic kidney disease. Am J Nephrol 2006;26:445-54.

17 Aggarwal HK, Nand N, Singh S, Singh M, Hemant, Kaushik G. Comparison of oral versus intravenous iron therapy in predialysis patients of chronic renal failure receiving recombinant human erythropoietin. J Assoc Physicians India 2003;51:170-4.

18 Al RA, Unlubilgin E, Kandemir O, Yalvac S, Cakir L, Haberal A. Intravenous versus oral iron for treatment of anemia in pregnancy: a randomized trial. Obstet Gynecol 2005;106:1335-40

19 Al-Momen AK, al-Meshari A, al-Nuaim L, Saddique A, Abotalib Z, Khashogji T, et al. Intravenous iron sucrose complex in the treatment of iron deficiency anemia during pregnancy. Eur J Obstet Gynecol Reprod Biol 1996;69:121-4.

20 Allen RP, Adler CH, Du W, Butcher A, Bregman DB, Earley CJ. Clinical efficacy and safety of IV ferric carboxymaltose (FCM) treatment of RLS: a multi-centred, placebo-controlled preliminary clinical trial. Sleep Med 2011;12:906-13.

21 Anker SD, Comin Colet J, Filippatos G, Willenheimer R, Dickstein K, Drexler H, et al. Ferric carboxymaltose in patients with heart failure and iron deficiency. $N$ Engl J Med 2009;361:2436-48.

22 Auerbach M, Ballard H, Trout JR, Mcllwain M, Ackerman A, Bahrain H, et al. Intravenous iron optimizes the response to recombinant human erythropoietin in cancer patients with chemotherapy-related anemia: a multicenter, open-label, randomized trial. J Clin Oncol 2004;22:1301-7.

23 Auerbach M, Silberstein PT, Webb RT, Averyanova S, Ciuleanu TE, Shao J, et al. Darbepoetin alfa 300 or 500 mug once every 3 weeks with or without intravenous iron in patients with chemotherapy-induced anemia. Am J Hematol 2010;85:655-63.

24 Bastit L, Vandebroek A, Altintas S, Gaede B, Pinter T, Suto TS, et al. Randomized, multicenter, controlled trial comparing the efficacy and safety of darbepoetin alpha administered every 3 weeks with or without intravenous iron in patients with chemotherapy-induced anemia. J Clin Oncol 2008;26:1611-8.

25 Bayoumeu F, Subiran-Buisset C, Baka NE, Legagneur H, Monnier-Barbarino P, Laxenaire $M C$. Iron therapy in iron deficiency anemia in pregnancy: intravenous route versus oral route. Am J Obstet Gynecol 2002;186:518-22.

26 Beck-da-Silva L, Piardi D, Soder S, Rohde LE, Pereira-Barretto AC, de Albuquerque D, et al. IRON-HF study: a randomized trial to assess the effects of iron in heart failure patients with anemia. Int J Cardiol 2013 doi:10.1016/j.jijcard.2013.04.181

27 Bencaiova G, von Mandach U, Zimmermann R. Iron prophylaxis in pregnancy: intravenous route versus oral route. Eur J Obstet Gynecol Reprod Biol 2009;144:135-9.

28 Bhandal N, Russell R. Intravenous versus oral iron therapy for postpartum anaemia. BJOG 2006;113:1248-52.

29 Birgegard G, Schneider K, Ulfberg J. High incidence of iron depletion and restless leg syndrome (RLS) in regular blood donors: intravenous iron sucrose substitution more effective than oral iron. Vox Sang 2010;99:354-61.

30 Breymann C, Gliga F, Bejenariu C, Strizhova N. Comparative efficacy and safety of intravenous ferric carboxymaltose in the treatment of postpartum iron deficiency anemia. Int J Gynaecol Obstet 2008:101:67-73.

31 Charytan C, Qunibi W, Bailie GR. Comparison of intravenous iron sucrose to oral iron in the treatment of anemic patients with chronic kidney disease not on dialysis. Nephron Clin Pract 2005;100:c55-62.

32 Coyne DW, Kapoian T, Suki W, Singh AK, Moran JE, Dahl NV, et al. Ferric gluconate is highly efficacious in anemic hemodialysis patients with high serum ferritin and low transferrin saturation: results of the Dialysis Patients' Response to IV Iron with Elevated transferrin saturation: results of the Dialysis Patients' Response

33 Dangsuwan $\mathrm{P}$, Manchana T. Blood transfusion reduction with intravenous iron in gynecologic cancer patients receiving chemotherapy. Gynecol Oncol 2010;116:522-5.

34 Edwards TJ, Noble EJ, Durran A, Mellor N, Hosie KB. Randomized clinical trial of preoperative intravenous iron sucrose to reduce blood transfusion in anaemic patients after colorectal cancer surgery. Br J Surg 2009:96:1122-8.

35 Evstatiev R, Alexeeva O, Bokemeyer B, Chopey I, Felder M, Gudehus M, et al. Ferric carboxymaltose prevents recurrence of anemia in patients with inflammatory bowel disease. Clin Gastroenterol Hepatol 2013;11:269-77.

36 Friel JK, Andrews WL, Hall MS, Rodway MS, Keith M, McCloy UC, et al. Intravenous iron administration to very-low-birth-weight newborns receiving total and partial parenteral nutrition. JPEN J Parenter Enteral Nutr 1995;19:114-8. 


\section{What is already known on this topic}

Intravenous iron therapy is effective at increasing haemoglobin concentration in patients with iron deficiency anaemia

\section{What this study adds}

Intravenous iron therapy can effectively reduce the need for red blood cell transfusion across a range of acute care settings The benefit of intravenous iron in increasing haemoglobin concentration was seen when compared with both oral iron and no iron supplementation and was more effective when used with erythroid stimulating agents and in patients with lower baseline plasma ferritin concentrations

Intravenous iron therapy was associated with an increased risk of infection

37 Froessler B, Cocchiaro C, Saadat-Gilani K, Hodyl N, Dekker G. Intravenous iron sucrose versus oral iron ferrous sulfate for antenatal and postpartum iron deficiency anemia: randomized trial. J Matern Fetal Neona 2013;26:654-9.

38 Garrido-Martin P, Nassar-Mansur MI, de la Llana-Ducros R, Virgos-Aller TM, Rodriguez Fortunez PM, Avalos-Pinto R, et al. The effect of intravenous and oral iron administration on perioperative anaemia and transfusion requirements in patients undergoing elective cardiac surgery: a randomized clinical trial. Interac Cardiovasc Thorac Surg 2012;15:1013-8.

39 Grote L, Leissner L, Hedner J, Ulfberg J. A randomized, double-blind, placebo controlled, multi-center study of intravenous iron sucrose and placebo in the treatment of restless legs syndrome. Mov Disord 2009;24:1445-52.

40 Hedenus M, Birgegard G, Nasman P, Ahlberg L, Karlsson T, Lauri B, et al. Addition of intravenous iron to epoetin beta increases hemoglobin response and decreases epoetin dose requirement in anemic patients with lymphoproliferative malignancies: a randomized multicenter study. Leukemia 2007;21:627-32.

41 Henry DH, Dahl NV, Auerbach M, Tchekmedyian S, Laufman LR. Intravenous ferric gluconate significantly improves response to epoetin alfa versus oral iron or no iron in anemic patients with cancer receiving chemotherapy. Oncologist 2007;12:231-42.

42 Hulin S, Durandy Y. [Post-haemodilution anaemia in paediatric cardiac surgery: benefit of intravenous iron therapy]. Ann Fr Anesth Reanim 2005;24:1262-5.

43 Karkouti K, McCluskey SA, Ghannam M, Salpeter MJ, Quirt I, Yau TM. Intravenous iron and recombinant erythropoietin for the treatment of postoperative anemia. Can J Anaesth 2006;53:11-9

44 Kasper SM, Lazansky H, Stark C, Klimek M, Laubinger R, Borner U. Efficacy of oral iron supplementation is not enhanced by additional intravenous iron during autologous blood donation. Transfusion 1998;38:764-70.

45 Khalafallah A, Dennis A, Bates J, Bates G, Robertson IK, Smith L, et al. A prospective randomized, controlled trial of intravenous versus oral iron for moderate iron deficiency anaemia of pregnancy. $J$ Intern Med 2010;268:286-95.

$46 \mathrm{Kim}$ YH, Chung HH, Kang SB, Kim SC, Kim YT. Safety and usefulness of intravenous iron sucrose in the management of preoperative anemia in patients with menorrhagia: phase IV, open-label, prospective, randomized study. Acta Haematol 2009;121:37-41.

$47 \mathrm{Kim}$ YT, Kim SW, Yoon BS, Cho HJ, Nahm EJ, Kim SH, et al. Effect of intravenously administered iron sucrose on the prevention of anemia in the cervical cancer patients treated with concurrent chemoradiotherapy. Gynecol Oncol 2007;105:199-204.

48 Kochhar PK, Kaundal A, Ghosh P. Intravenous iron sucrose versus oral iron in treatmen of iron deficiency anemia in pregnancy: a randomized clinical trial. J Obstet Gynaecol Res 2013;39:504-10.

49 Krayenbuehl PA, Battegay E, Breymann C, Furrer J, Schulthess G. Intravenous iron for the treatment of fatigue in nonanemic, premenopausal women with low serum ferritin concentration. Blood 2011;118:3222-7.

50 Kulnigg S, Stoinov S, Simanenkov V, Dudar LV, Karnafel W, Garcia LC, et al. A nove intravenous iron formulation for treatment of anemia in inflammatory bowel disease: the ferric carboxymaltose (FERINJECT) randomized controlled trial. Am J Gastroenterol 2008;103:1182-92.

$51 \mathrm{Li} \mathrm{H}$, Wang SX. Intravenous iron sucrose in peritoneal dialysis patients with renal anemia. Perit Dial Int 2008;28:149-54

52 Li H, Wang SX. Intravenous iron sucrose in Chinese hemodialysis patients with renal anemia. Blood Purif 2008:26:151-6.

$53 \mathrm{Li} \mathrm{H}$. [Intravenous iron sucrose in maintenance dialysis patients with renal anemia: a clinical study.] Zhonghua Yi Xue Za Zhi 2009;89:457-62.

54 Lindgren S, Wikman O, Befrits R, Blom H, Eriksson A, Granno C, et al. Intravenous iron sucrose is superior to oral iron sulphate for correcting anaemia and restoring iron stores in IBD patients: a randomized, controlled, evaluator-blind, multicentre study. Scand J Gastroenterol 2009:44:838-45.

55 Maccio A, Madeddu C, Gramignano G, Mulas C, Sanna E, Mantovani G. Efficacy and safety of oral lactoferrin supplementation in combination with rHuEPO-beta for the treatment of anemia in advanced cancer patients undergoing chemotherapy: open-label, randomized controlled study. Oncologist 2010;15:894-902.

56 Macdougall IC, Tucker B, Thompson J, Tomson CR, Baker LR, Raine AE. A randomized controlled study of iron supplementation in patients treated with erythropoietin. Kidney Int 1996:50:1694-9.

57 Madi-Jebara SN, Sleilaty GS, Achouh PE, Yazigi AG, Haddad FA, Hayek GM, et al. Postoperative intravenous iron used alone or in combination with low-dose erythropoietin is not effective for correction of anemia after cardiac surgery. J Cardiothorac Vasc Anesth 2004;18:59-63.

58 McMahon LP, Kent AB, Kerr PG, Healy H, Irish AB, Cooper B, et al. Maintenance of elevated versus physiological iron indices in non-anaemic patients with chronic kidney disease: a randomized controlled trial. Nephrol Dial Transplant 2010;25:920-6.

59 Meyer MP, Haworth C, Meyer JH, Commerford A. A comparison of oral and intravenous iron supplementation in preterm infants receiving recombinant erythropoietin. $J$ Pediatr 1996;129:258-63

$60 \mathrm{Na} \mathrm{HS}$, Shin SY, Hwang JY, Jeon YT, Kim CS, Do SH. Effects of intravenous iron combined with low-dose recombinant human erythropoietin on transfusion requirements in iron-deficient patients undergoing bilateral total knee replacement arthroplasty Transfusion 2011;51:118-24.

61 Okonko DO, Grzeslo A, Witkowski T, Mandal AK, Slater RM, Roughton M, et al. Effect of intravenous iron sucrose on exercise tolerance in anemic and nonanemic patients with symptomatic chronic heart failure and iron deficiency FERRIC-HF: a randomized, controlled, observer-blinded trial. J Am Coll Cardiol 2008;51:103-12.

62 Olijhoek G, Megens JG, Musto P, Nogarin L, Gassmann-Mayer C, Vercammen E, et al. Role of oral versus IV iron supplementation in the erythropoietic response to rHuEPO: a randomized, placebo-controlled trial. Transfusion 2001;41:957-63.

63 Onken JE, Bregman DB, Harrington RA, Morris D, Acs P, Akright B, et al. A multicenter, randomized, active-controlled study to investigate the efficacy and safety of intravenous ferric carboxymaltose in patients with iron deficiency anemia. Transfusion 2013 doi:10. $1111 /$ trf. 12289

64 Pedrazzoli P, Farris A, Del Prete S, Del Gaizo F, Ferrari D, Bianchessi C, et al. Randomized trial of intravenous iron supplementation in patients with chemotherapy-related anemia without iron deficiency treated with darbepoetin alpha. J Clin Oncol 2008:26:1619-25.

65 Pollak A, Hayde M, Hayn M, Herkner K, Lombard KA, Lubec G, et al. Effect of intravenous iron supplementation on erythropoiesis in erythropoietin-treated premature infants. Pediatrics 2001;107:78-85.

66 Provenzano R, Schiller B, Rao M, Coyne D, Brenner L, Pereira BJ. Ferumoxytol as an intravenous iron replacement therapy in hemodialysis patients. Clin J Am Soc Nephrol 2009;4:386-93.

67 Qunibi WY, Martinez C, Smith M, Benjamin J, Mangione A, Roger SD. A randomized controlled trial comparing intravenous ferric carboxymaltose with oral iron for treatment of iron deficiency anaemia of non-dialysis-dependent chronic kidney disease patients. Nephrol Dial Transplant 2011;26:1599-607.

68 Schaller G, Scheiber-Mojdehkar B, Wolzt M, Puttinger H, Mittermayer F, Horl WH, et al. Intravenous iron increases labile serum iron but does not impair forearm blood flow reactivity in dialysis patients. Kidney Int 2005;68:2814-22.

69 Schindler E, Scholz S, Boldt J, Zickmann B, Knothe C, Dietrich G, et al. [Effectiveness of oral versus parenteral iron substitution in autologous blood donors]. Infusionsther Transfusionsmed 1994;21:236-41.

70 Schroder O, Mickisch O, Seidler U, de Weerth A, Dignass AU, Herfarth H, et al. Intravenous iron sucrose versus oral iron supplementation for the treatment of iron deficiency anemia in patients with inflammatory bowel disease-a randomized, controlled, open-label, multicenter study. Am J Gastroenterol 2005;100:2503-9.

71 Seid MH, Derman RJ, Baker JB, Banach W, Goldberg C, Rogers R. Ferric carboxymaltose injection in the treatment of postpartum iron deficiency anemia: a randomized controlled clinical trial. Am J Obstet Gynecol 2008:199:435

72 Serrano-Trenas JA, Ugalde PF, Cabello LM, Chofles LC, Lazaro PS, Benitez PC. Role of perioperative intravenous iron therapy in elderly hip fracture patients: a single-center randomized controlled trial. Transfusion 2011;51:97-104

73 Shafi D, Purandare SV, Sathe AV. Iron deficiency anemia in pregnancy: intravenous versus oral route. J Obstet Gynaecol India 2012;62:317-21.

74 Singh H, Reed J, Noble S, Cangiano JL, Van Wyck DB. Effect of intravenous iron sucrose in peritoneal dialysis patients who receive erythropoiesis-stimulating agents for anemia: a randomized, controlled trial. Clin J Am Soc Nephrol 2006;1:475-82.

75 Singh K, Fong YF, Kuperan P. A comparison between intravenous iron polymaltose complex (Ferrum Hausmann) and oral ferrous fumarate in the treatment of iron deficiency anaemia in pregnancy. Eur $J$ Haematol 1998;60:119-24.

76 Sloand JA, Shelly MA, Feigin A, Bernstein P, Monk RD. A double-blind, placebo-controlled trial of intravenous iron dextran therapy in patients with ESRD and restless legs syndrome. Am J Kidney Dis 2004;43:663-70.

77 Spinowitz BS, Kausz AT, Baptista J, Noble SD, Sothinathan R, Bernardo MV, et al Ferumoxytol for treating iron deficiency anemia in CKD. J Am Soc Nephrol 2008;19:1599-605

78 Steensma DP, Sloan JA, Dakhil SR, Dalton R, Kahanic SP, Prager DJ, et al. Phase III, randomized study of the effects of parenteral iron, oral iron, or no iron supplementation on the erythropoietic response to darbepoetin alfa for patients with chemotherapy-associated anemia. J Clin Oncol 2011;29:97-105.

79 Stoves J, Inglis H, Newstead CG. A randomized study of oral vs intravenous iron supplementation in patients with progressive renal insufficiency treated with erythropoietin. Nephrol Dial Transplant 2001;16:967-74

80 Toblli JE, Lombrana A, Duarte P, Di Gennaro F Intravenous iron reduces NT-pro-brain natriuretic peptide in anemic patients with chronic heart failure and renal insufficiency. $J$ Am Coll Cardiol 2007;50:1657-65.

81 Van Iperen CE, Gaillard CA, Kraaijenhagen RJ, Braam BG, Marx JJ, van de Wiel A Response of erythropoiesis and iron metabolism to recombinant human erythropoietin in intensive care unit patients. Crit Care Med 2000;28:2773-8.

82 Van Wyck DB, Martens MG, Seid MH, Baker JB, Mangione A. Intravenous ferric carboxymaltose compared with oral iron in the treatment of postpartum anemia: a randomized controlled trial. Obstet Gynecol 2007;110:267-78.

83 Van Wyck DB, Mangione A, Morrison J, Hadley PE, Jehle JA, Goodnough LT. Large-dose intravenous ferric carboxymaltose injection for iron deficiency anemia in heavy uterine bleeding: a randomized, controlled trial. Transfusion 2009;49:2719-28.

84 Van Wyck DB, Roppolo M, Martinez CO, Mazey RM, McMurray S. A randomized, controlled trial comparing IV iron sucrose to oral iron in anemic patients with nondialysis-dependent CKD. Kidney Int 2005;68:2846-56.

85 Verma S. Intravenous iron therapy versus oral iron in postpartum patients in rural areas. J S Asian Fed Obstet Gynaecol 2011;3:67-70.

86 Warady BA, Kausz A, Lerner G, Brewer ED, Chadha V, Brugnara C, et al. Iron therapy in the pediatric hemodialysis population. Pediatr Nephrol 2004;19:655-61. 
87 Weisbach V, Skoda P, Rippel R, Lauer G, Glaser A, Zingsem J, et al. Oral or intravenous iron as an adjuvant to autologous blood donation in elective surgery: a randomized, controlled study. Transfusion 1999;39:465-72.

88 Westad S, Backe B, Salvesen KA, Nakling J, Okland I, Borthen I, et al. A 12-week randomised study comparing intravenous iron sucrose versus oral ferrous sulphate for treatment of postpartum anemia. Acta Obstet Gynecol Scand 2008;87:916-23.

89 Marik PE, Corwin HL. Efficacy of red blood cell transfusion in the critically ill: a systematic review of the literature. Critical care medicine 2008:36:2667-74.

90 Fleming RE, Ponka P. Iron overload in human disease. N Engl J Med 2012;366:348-59.

91 Goodnough LT, Nemeth E, Ganz T. Detection, evaluation, and management of iron-restricted erythropoiesis. Blood 2010;116:4754-61.

92 Corwin HL, Gettinger A, Fabian TC, May A, Pearl RG, Heard S, et al. Efficacy and safety of epoetin alfa in critically ill patients. N Engl J Med 2007;357:965-76.

93 Heming N, Letteron P, Driss F, Millot S, El Benna J, Tourret J, et al. Efficacy and toxicity of intravenous iron in a mouse model of critical care anemia*. Crit Care Med 2012;40:2141-8

94 Torres S, Kuo YH, Morris K, Neibart R, Holtz JB, Davis JM. Intravenous iron following cardiac surgery does not increase the infection rate. Surg Infect (LarChmt) 2006;7:361-6.

95 Ang O, Gungor M, Aricioglu F, Inanc D, Sagduyu $\mathrm{H}$, Uysal V, et al. The effect of parentera iron administration on the development of Staphylococcus aureus-induced experimental pyelonephritis in rats. Int J Exp Pathol 1990;71:507-11.

96 Locatelli F, Del Vecchio L. New erythropoiesis-stimulating agents and new iron formulations. Contrib Nephrol 2011;171:255-60
97 Moore RA, Gaskell H, Rose P, Allan J. Meta-analysis of efficacy and safety of intravenous ferric carboxymaltose (Ferinject) from clinical trial reports and published trial data. $B M C$ Blood Disord 2011;11:4

98 Gafter-Gvili A, Rozen-Zvi B, Vidal L, Leibovici L, Vansteenkiste J, Gafter U, et al. Intravenous iron supplementation for the treatment of chemotherapy-induced anaemiasystematic review and meta-analysis of randomised controlled trials. Acta Oncol 2013;52:18-29.

99 Stewart GB, Altman DG, Askie LM, Duley L, Simmonds MC, Stewart LA. Statistical analysis of individual participant data meta-analyses: a comparison of methods and recommendations for practice. PLoS One 2012;7:e46042.

Accepted: 13 July 2013

\section{Cite this as: BMJ 2013;347:f4822}

This is an Open Access article distributed in accordance with the Creative Commons Attribution Non Commercial (CC BY-NC 3.0) license, which permits others to distribute, remix, adapt, build upon this work non-commercially, and license their derivative works on different terms, provided the original work is properly cited and the use is non-commercial. See: http://creativecommons.org/licenses/by-nc/3.0/. 


\section{Figures}

Potentially relevant studies identified and screened for retrieval $(n=1815)$

$\rightarrow$ Not a randomised controlled study, no intravenous iron, no outcomes of interest $(n=1689)$

Studies retrieved for more detailed evaluation $(n=126)$

Excluded $(n=51)$

No intravenous iron group or comparison without intravenous iron $(n=18)$

Not randomised controlled study $(n=12)$

- Abstract only ( $n=11)$

No outcomes of interest $(n=5)$

Crossover study $(\mathrm{n}=3)$

Duplicate publication $(n=2)$

Studies with 10879 participants included in systematic review $(n=75)$

Did not report outcome, or data insufficient for pooling $(n=3)$

Studies with 10605 participants reporting one or more outcome included in meta-analysis $(n=72)$

Change in haemoglobin analysis $(n=59) \quad$ Serious adverse event analysis $(n=5)$

Infection analysis $(n=24)$

Mortality analysis $(n=3)$

Transfusion analysis $(n=11)$

Fig 1 Flow diagram of selection of studies on intravenous iron therapy 


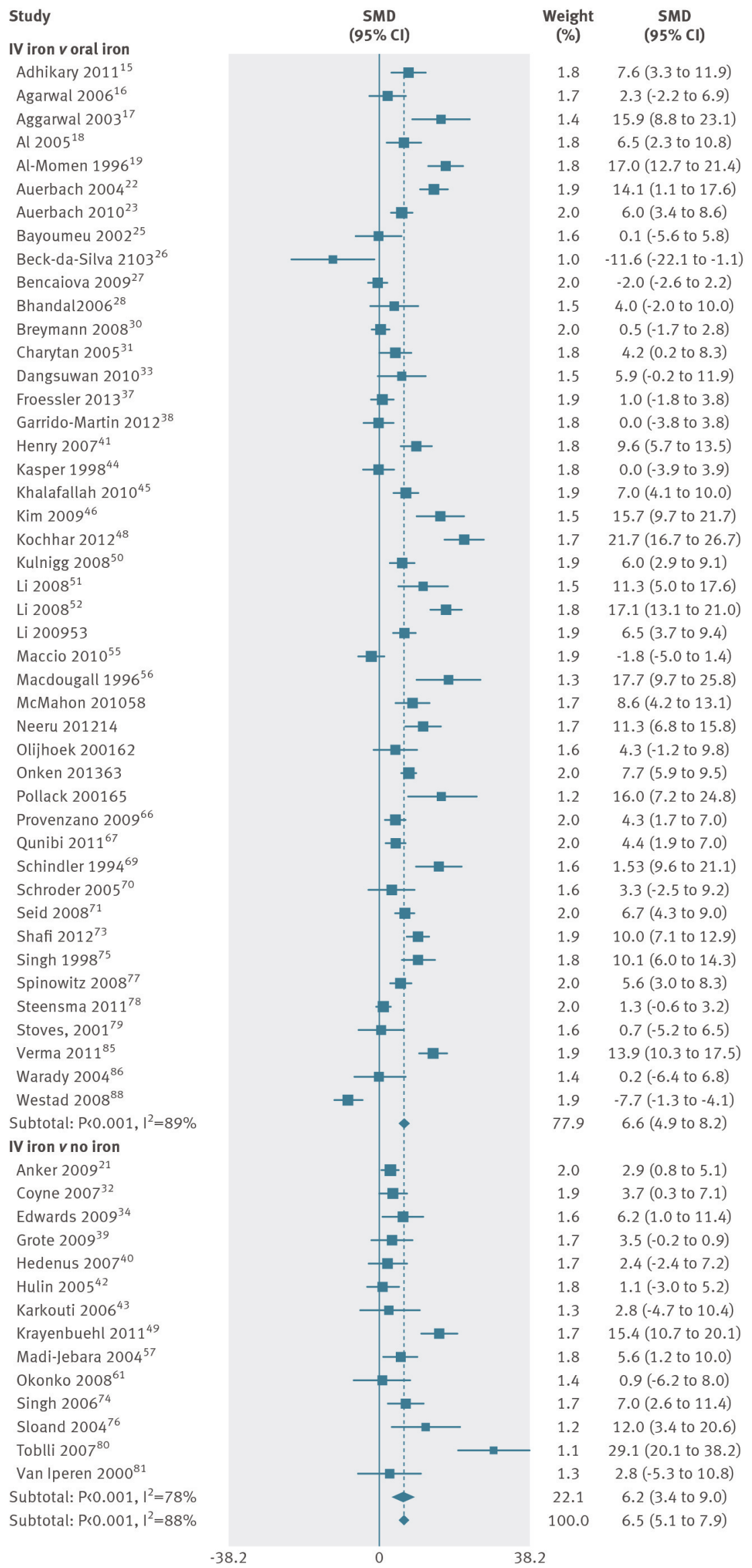

Fig 2 Standardised mean difference in haemoglobin $(\mathrm{g} / \mathrm{L})$ in patients who received intravenous iron compared with oral iron and no iron. Weights are from random effects analysis 


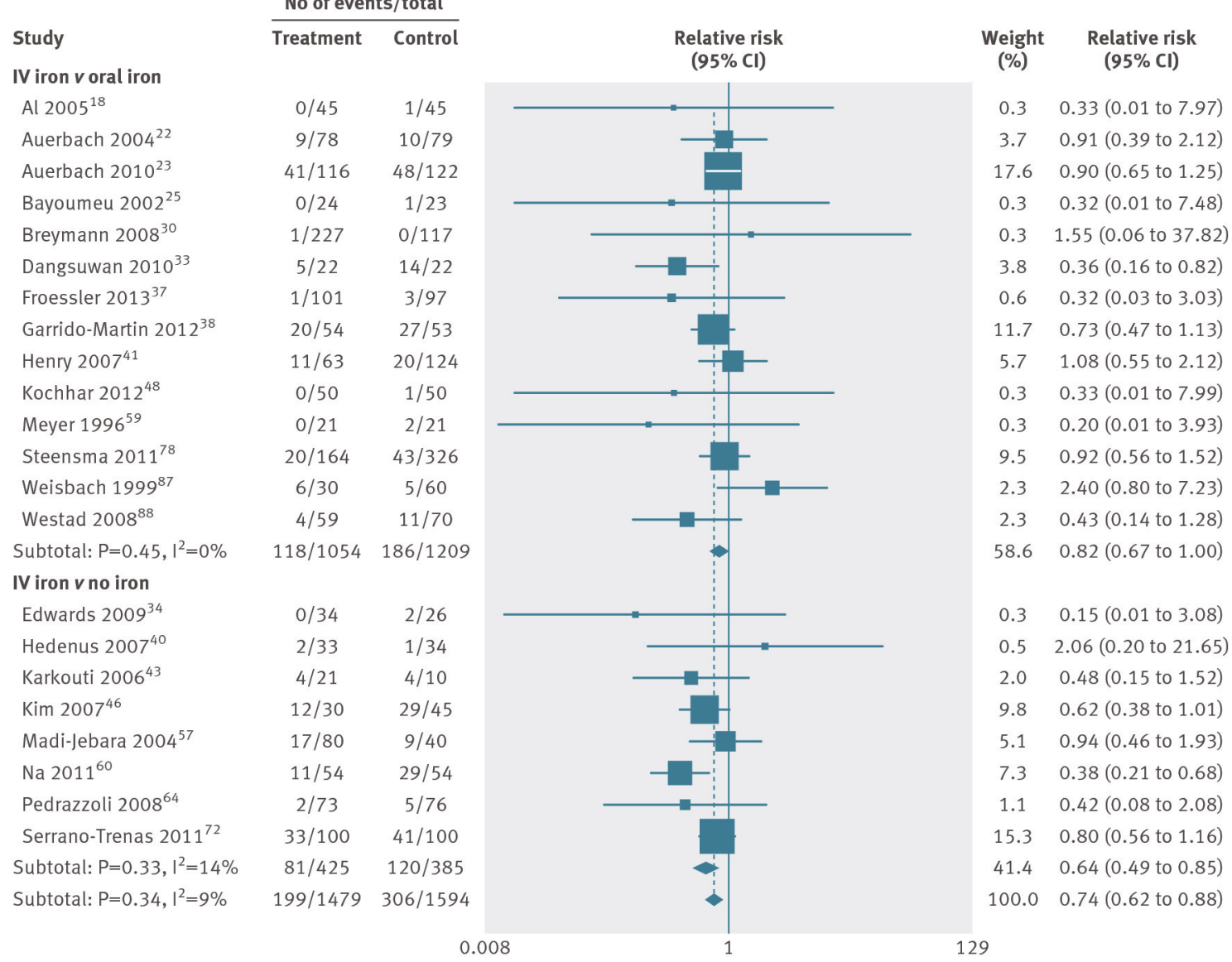

Fig 3 Risk of red blood cell transfusion in patients who received intravenous iron compared with oral iron and no iron. Weights are from random effects analysis

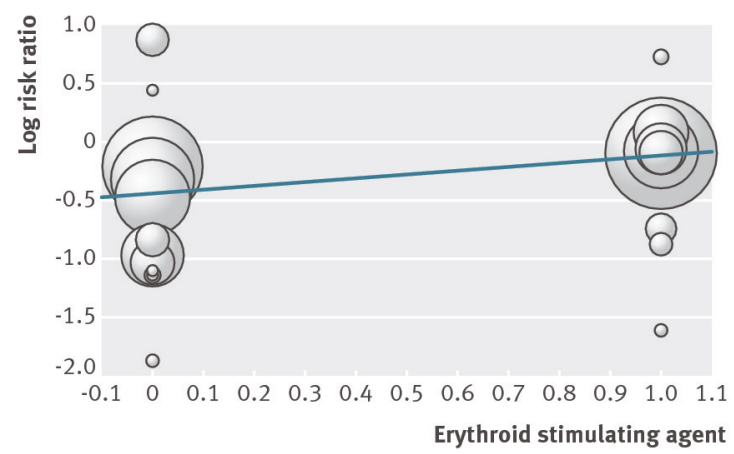

Fig 4 Regression of erythroid stimulating agent on log risk ratio of red blood cell transfusion. Slope of regression line 0.32 , $95 \%$ confidence interval 0.02 to $0.63 ; P=0.04$ ) 


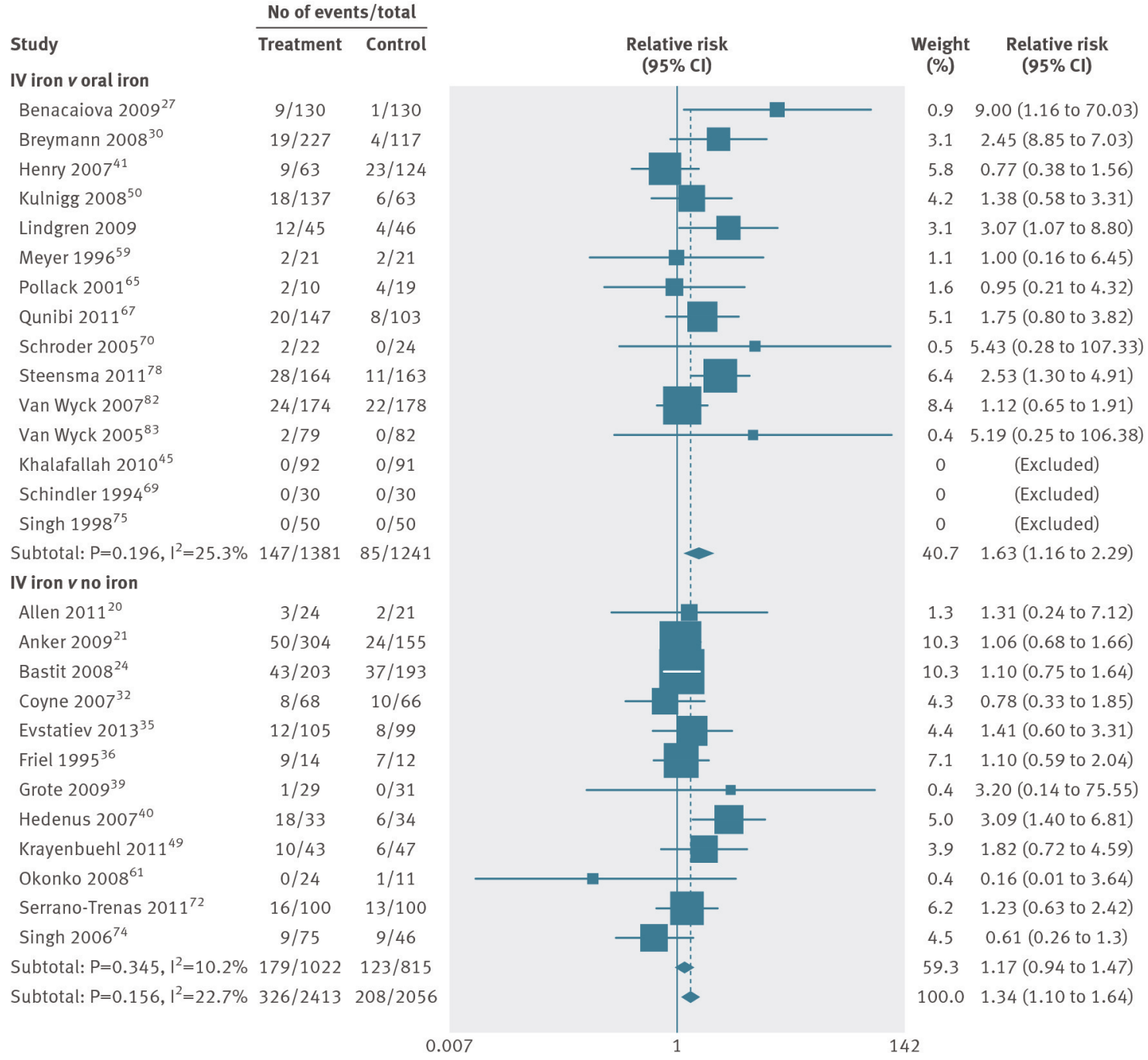

Fig 5 Risk of infection in patients who received intravenous iron. Weights are from random effects analysis

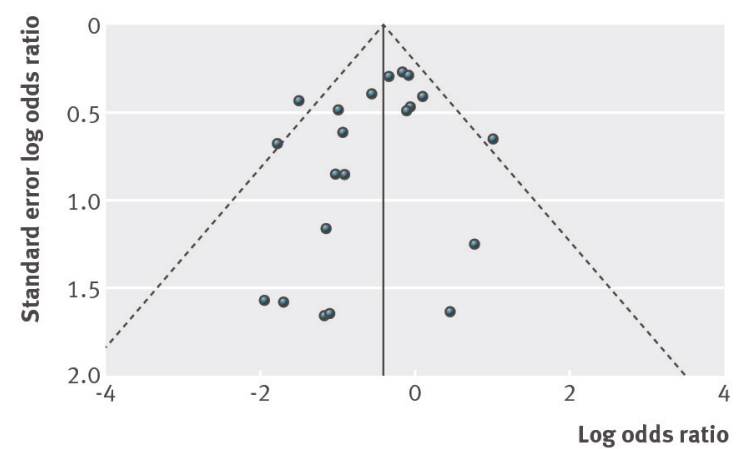

Fig 6 Odds ratio of transfusion against standard error of log odds ratio 